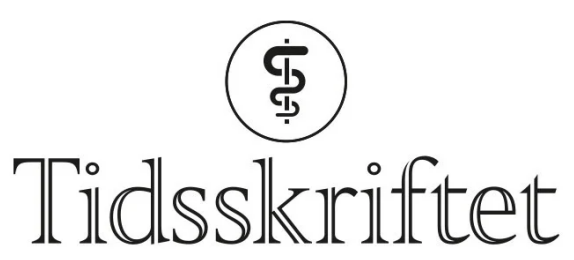

DEN NORSKE LEGEFORENING

\title{
Utredning av anemi
}

\author{
BREV TIL REDAKTØREN
}

\section{FREDRIK SCHJESVOLD}

Fredrik Schjesvold (f. 1975) er spesialist i indremedisin, konstituert hematolog på Bærum sykehus og stipendiat i tumorimmunologi ved Oslo universitetssykehus. Ingen oppgitte interessekonflikter.

Email: fredrik.hellem.schjesvold@vestreviken.no

\section{KRISTINE WIENCKE}

Kristine Wiencke (f. 1963) er overlege i gastroenterologi ved Bærum sykehus. Ingen oppgitte interessekonflikter.

\section{GEIR E. TJØNNFJORD}

Geir E. Tjønnfjord (f. 1953) er avdelingsleder ved Avdeling for blodsykdommer, Oslo Universitetssykehus.

Ingen oppgitte interessekonflikter. 


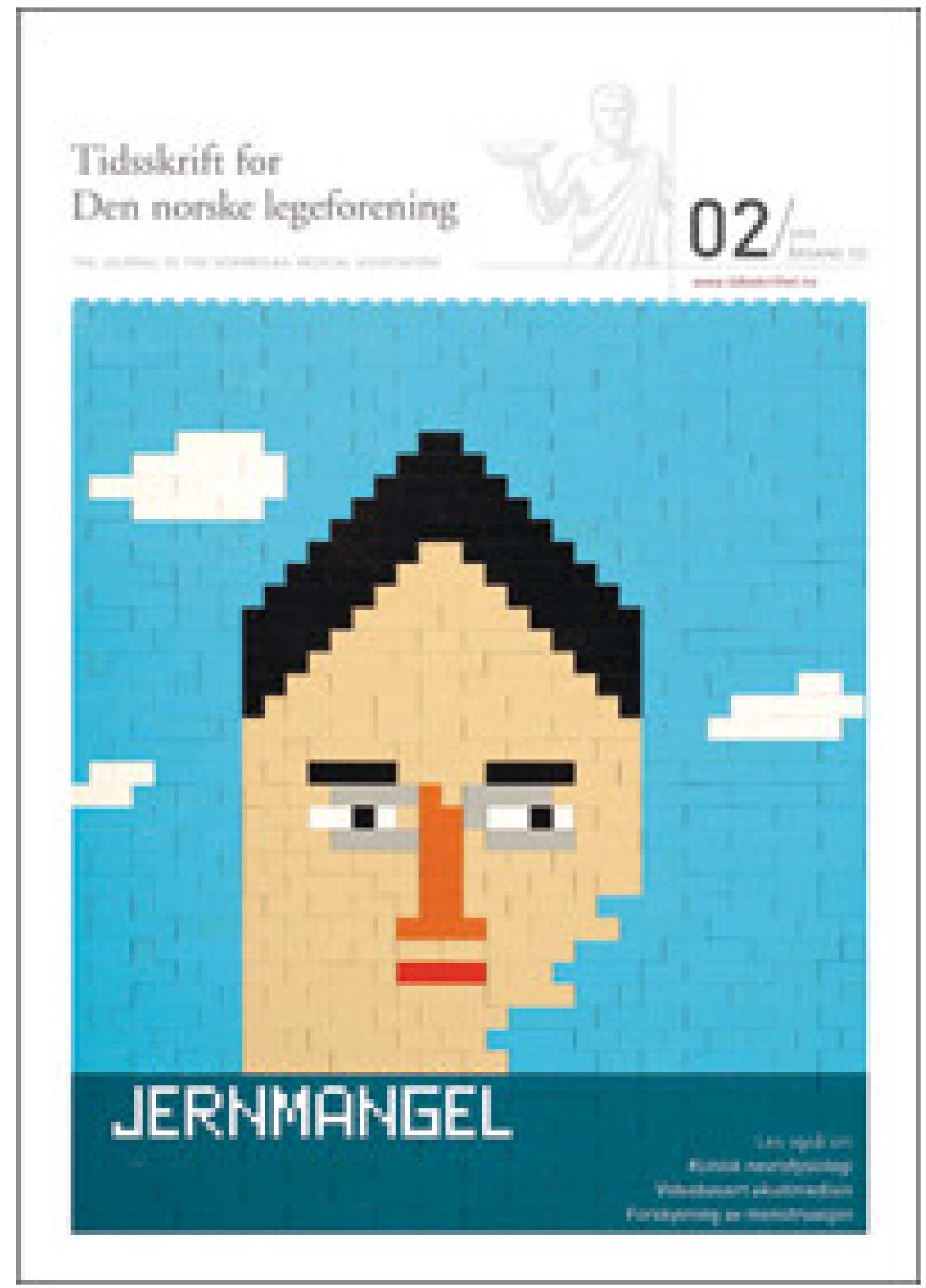

I Tidsskriftet nr. 2/2013 har Tor-Arne Hagve og medarbeidere en oversiktsartikkel om utredning av jernmangelanemi (1). Temaet er meget viktig av flere grunner; den viktigste er at anemi ofte er et symptom på alvorlig sykdom. I artikkelen blir jernmetabolismen og de forskjellige prøvenes sensitivitet og spesifisitet for påvisning av jernmangel forklart på en god måte.

Det er riktig at ferritin er den beste markøren for jernmangel, og det er også riktig at man kan ha jernmangel ved et høyere ferritinnivå enn $20 \mu \mathrm{g} / \mathrm{l}$, som er en vanlig «beslutningsgrense». Hvilket nivå som kan utelukke jernmangel er usikkert, og dette diskuteres godt av artikkelforfatterne.

Dessverre mener vi den selvlagede algoritmen for utredning av anemi, som har som målsetting å sikre at pasienter med jernmangel blir identifisert, ikke er et hensiktsmessig verktøy ved anemiutredning. Problemet i den praktiske hverdagen, både i indremedisinske avdelinger og i allmennpraksis, er at det er overdiagnostisering og overbehandling av 
jernmangel som årsak til anemi, underdiagnos-tisering av andre årsaker til anemi og mangelfull utredning av årsaker til jernmangel. At inflammasjon øker ferritinnivået oppfattes av mange som at ferritin ikke kan brukes i akuttfasen. Som forfatterne skriver, er dette ikke riktig, og jernmangel kan utelukkes ved høye ferritinnivåer.

Det er riktig at MCV ikke er sensitivt nok til å utelukke jernmangel, og at løselig transferrinreseptor (TfR) er mer sensitivt. Men man kan ikke uten videre slutte fra dette at TfR er bedre enn MCV ved anemidiagnostikk, tvert imot. Hvis MCV er under referanseområdet er mulighetene få. Da er det kun snakk om jernmangel, anemi ved kronisk sykdom eller hemoglobinopati, og disse alternativene er vanligvis relativt enkle å skille fra hverandre; artikkelen gir god veiledning. Bruk av MCV som sorteringsparameter gjør derfor diagnosen lett å stille hos de fleste pasientene. TfR derimot sier lite hvis verdien er høy. Som forfatterne sier, kan det da være hemolyse, leukemier, myelodysplastisk syndrom eller jernmangel. Man er så godt som like langt. Hvis TfR-verdien er normal, er den nyttig for å ekskludere jernmangel.

Algoritmen som presenteres i artikkelen, kan brukes hos gravide og hos pasienter med lav MCV. Hos alle andre kan den være potensielt villedende og tidvis farlig. Hvis en pasient med en annen årsak til anemi enn jernmangel, har CRP $>5 \mathrm{mg} / \mathrm{l}$ og ferritin $>30 \mu \mathrm{g} / \mathrm{l}$, eller ferritin $>\mathbf{2 0 0} \mu \mathrm{g} / \mathrm{l}$ (dette gjelder de aller fleste pasienter på en indremedisinsk avdeling), vil konklusjonen bli anemi ved kronisk sykdom, eventuelt med tillegg av jernmangel, og det vil ikke være nødvendig med videre utredning av anemien. Man mister da de fleste pasientene med hematologisk årsak til anemi, en relativt stor gruppe med potensielt dødelige sykdommer.

Oppsummert kan det fremstilles på denne måten:

- Ved å fokusere på TfR øker man overdiagnostisering av jernmangel, noe som allerede er et stort problem sett fra vårt ståsted.

- Ved å si at «andre biokjemiske og hematologiske analyser gir lite diagnostisk informasjon i tillegg» gjør man en grov feil. Retikulocytter, som ikke er nevnt, er uunnværlig for å finne en anemi der produksjonen ikke er problemet, som f.eks. ved hemolytisk anemi. Nytten av MCV i anemiutredningen er beskrevet over.

- Algoritmen som forfatterne foreslår, bærer preg av sterkt og ensidig søkelys på jernmangel i anemiutredning. Ved å følge algoritmen vil avdekking av andre årsaker til anemi forsinkes, og i verste fall ikke oppdages før det er for sent.

Dette er en redigert versjon av et innlegg publisert som rask respons på nett 13.2. 2013 http:/|tidsskriftet.no/article/2961116/

\section{LITTERATUR}

1. Hagve T-A, Lilleholt K, Svendsen M. Jernmangelanemi - tolking av biokjemiske og hematologiske funn. Tidsskr Nor Legeforen 2013; 133:161-4. [PubMed]

Publisert: 19. mars 2013. Tidsskr Nor Legeforen. DOI: 10.4045/tidsskr.13.0256

(C) Tidsskrift for Den norske legeforening 2023. Lastet ned fra tidsskriftet.no 26. april 2023. 